\title{
Evaluation of Some Reproductive Parameters of Tsurcana Sheep Crossed with Blanc du Massif Central Rams
}

\author{
Mihai Marian BORZAN ${ }^{1 *}$, Adrian CÎMPEAN ${ }^{1}$, Dana PUSTA ${ }^{1}$, Ioan PAȘCA ${ }^{1}$ \\ ${ }^{1}$ Department of Animal Productions and Food Safety, USAMV Cluj, Romania \\ *Corresponding author: mihai_borzan@yahoo.com
}

Bulletin UASVM Veterinary Medicine 72(2) / 2015,

Print ISSN 1843-5270; Electronic ISSN 1843-5378

DOI:10.15835/buasvmcn-vm: 11639

\begin{abstract}
The European market demands a better conformation in sheep carcass (class U or R). This carcass quality cannot be achieved in local Romanian breed - Tsurcana and Tsigaia - without a crossing with a specialized meat breed. The study was conducted with the aim to evaluate the fertility rate, in order to compare some reproductive parameters between the Tsurcana breed (Tsurcana rams x Tsurcana ewes) and the Blanc du Massif Central rams crossed with Tsurcana ewes. The research was conducted on a selected flock of 100 Tsurcana sheep that were divided in two batches: 50 ewes were mated with Tsurcana rams and 50 ewes were mated with 2 young Blanc du Massif Central rams, recently imported from France. The sheep included in the study were hormonal synchronized with progesterone and eCG (Equine Chorionic Gonadotropin). After mating the pregnancy diagnosis was performed by ultrasound examination at 55 and 130 days. The conceiving, the fecundity and prolificacy rate were assessed. The results were similar between the two batches concerning the conceiving, prolificacy and fecundity rate (Tsurcana rams x Tsurcana Ewes and Blanc du Massif Central rams and Tsurcana ewes).
\end{abstract}

Keywords: Blanc du Massif Central, fertility, fecundity, prolificacy rate, Tsurcana

\section{INTRODUCTION}

The European market demands a better conformation in sheep carcass (class $\mathrm{U}$ or $\mathrm{R}$ in EUROP classification). This carcass quality cannot be achieved in local Romanian breed - Tsurcana and Tsigaia - without a crossing with a specialized meat breed.

Low productivity is a feature of traditional extensive systems of sheep production. The seasonal breeding of sheep reduces the traditional viability of the traditional flock (Ptaszynska, 2009). Also, the meat quality produced by the Tsurcana breed is not suitable for the demands of the EU market. Therefore it is necessary to use the modern management systems of reproduction and even to cross the local breed with a specialized meat breed to obtain a lamb suitable for the demands of the European markets.

Nowadays the main production is sheep industry changed from the wool production towards the meat and milk production, in order to respond to the market demands. This major shift in sheep industry is also important for our country, because Romania has a great potential, having almost 9 million sheep (being the fourth European country after UK, Spain and Greece as number of sheep - FAO statistics (FAO STATISTICAL YEARBOOK 2014). The majority of the sheep in Romania are Tsurcana breed $(79,00 \%)$, which are not able to produce a quality meat competitive for the demands of the European occidental markets. The quality of the meat, the classification 
of the carcass and the price of the carcass is very different between the mentioned markets, making the Romanian sheep industry less profitable.

A good alternative for the Romanian sheep industry is to make a crossing with a specialized meat breed, in order to obtain better meat quality, without changing the purebred local livestock. The easiest way is to use good quality rams, which will improve the quality and quantity in the resulting generation (F1). The resulting lambs will benefit from the hybrid vigor and they will be very well adapted to the conditions and systems used in Romania.

The breed selected for these crossings was choose due to their adaptability to new conditions, rusticity and good meat production, both in quality and quantity. The breed selected was the French breed Blanc du Massif Central, which was created and selected in similar conditions found in Romania (altitude, rains, adaptation to low temperatures, etc.).

Aim: The study was conducted with the aim to evaluate the fertility, fecundity and prolificacy in order to compare some reproductive parameters between the Tsurcana breed (Tsurcana rams $\mathrm{x}$ Tsurcana ewes) and the Blanc du Massif Central rams crossed with Tsurcana ewes.

\section{MATERIALS AND METHODS}

The research was conducted on a selected flock of 100 Tsurcana sheep that were divided in two batches: the first batch of 50 ewes were mated with 2 young Blanc du Massif Central rams, recently imported from France; and the second batch of 50 ewes were mated with 2 Tsurcana rams.

The meat rams were selected from Blanc de Massif Central breed, after studying their genetics and their performances (they were imported from a specialized reproduction center from France). After the adaptation period, (about one month) they were used to mate local Tsurcana ewes.

The ewes included in the study were hormonal synchronized with progesterone and eCG (Equine Chorionic Gonadotropin). After mating the pregnancy diagnosis was performed by transabdominal ultrasound examination at 55 and 130 days (Rosa and Bryant, 2003).

The ewes included in the research were Tsurcana breed, clinical healthy, aged between 1 to 4 years old, without any known pathology and not pregnant. 100 ewes were selected and they were separated from the rest of the flock for two months prior to mating. Also nutritional supplements were administrated to the flock three weeks prior to mating (flushing) (Noakes et al., 2009).

The ewes were synchronized using vaginal sponges impregnated with $20 \mathrm{mg}$ cronolone (Chronogest $® C R$, produced by MSD Animal Health). The sponges were introduced in the vagina and left in place for 14 days. After the extraction, eCG (Equine chorionic Gonadotrophin) (Folligon - MSD Animal Health) was administered intramuscular, at a dose of 500 UI (Henderson and Robinson, 2000, Haresign, 1992, Groza, 2006).

The signs of estrus in ewes were observed 36- 66 hours later. After the onset of estrus selective mating was performed with the 4 rams ( 2 of Tsurcana breed and 2 of Blanc de Massif Central breed). The synchronization of estrus was performed in order to obtain 2 smaller groups of 50 ewes that were naturally mated with the 4 rams (to assure a normal ram to ewe ratio/ram). The groups were synchronized so that the ewes belonging to the groups could be mated at 5 days apart.

The pregnancy was determined after performing an ultrasound examination with a portable Mindray DP-2200 Vet Ultrasound, transabdominal, with a microconvex $5 \mathrm{MHz}$ probe.

The reproduction parameters evaluated were calculated after the following formulas (Ptaszynska, 2009):

$$
\begin{aligned}
& \text { fertility }=\frac{\text { numer of ewes lambing }}{\text { number of ewes exposed to the ram or } \mathrm{AI}} X 100 \\
& \text { prolificac } y=\frac{\text { number of lambs born (dead and alive) }}{\text { number of ewes lambing }} X 100 \\
& \text { fecundity }=\frac{\text { number of lambs born (dead and alive) }}{\text { number of ewes exposed to the ram or AI }} X 100
\end{aligned}
$$

\section{RESULTS AND DISCUSSIONS}

After assessing the fecundity, prolificacy, fertility and performing the pregnancy diagnosis by ultrasound, we obtained the following results (Table 1):

The ultrasound examination of the two batches of synchronized and mated ewes, the examination performed at 55 days revealed that in the first batch (the Tsurcana ewes mated with BMC rams), from 50 ewes included in the batch, only 48 ewes were pregnant. In the second batch 
(Tsurcana ewes mated with Tsurcana Rams) 49 ewes were pregnant.

The second ultrasound examination performed at 130 days after mating, revealed that in the first batch (Tsurcana ewes mated with BMC rams), only 44 ewes out of 48 ewes were still pregnant and in the second batch (Tsurcana ewes mated with Tsurcana Rams), 47 ewes were pregnant. The difference between the two ultrasound examinations (at 55 and 130 days) was recorded as abortion.

The fecundity results obtained for the second batch (Tsurcana ewes mated with Tsurcana rams) (96\%) are similar with the results obtained by other authors (Padeanu I. 2011, Daraban S. 2006), which obtained similar fecundity results (95\%) for natural mating in purebred Tsurcana flocks. The fecundity that calculated for the first batch (Tsurcana ewes mated with BMC rams) was lower $(92 \%)$ that the fertility of the second batch.

The fertility analysis revealed a difference between the two batches, in the first batch, the fertility being lower (88\%) than that obtained in the second batch (94\%). In literature, the fertility is considered to be influenced by many factors, like: breed, season, age, nutritional status, breeding management and farm conditions (Ptaszynska, 2009). Depending on the season, a fertility of $70-80 \%$ is considered to be normal or medium in breeding season and good or very good in out of the breeding season. The fertility results that we obtain in the research are above $80 \%$ in both studied batches ( $88 \%$ and $94 \%$ ).

The lambing analysis revealed that the lambing was grouped, the interval between the first and last lamb was 8 days, which corresponds with the synchronization of the two groups performed at 5 days apart to assure a normal ram to ewe ratio (Henderson D.C. and Robinson J.J 2000).

The prolificacy analysis for the first batch (104\%) was superior compared with the second batch (102\%), but for both batches the results were lower than that recorded by other authors (Padeanu, 2011, Daraban, 2006) for Tsurcana breed $-115 \%$. The prolificacy is influenced by the same factors that could affect fertility, but some breeds prove to be more prolific than others (eg Romanoff breed-350\%) (Ptaszynska, 2009).

\section{CONCLUSION}

In the batch of Tsurcana ewes mated with Blanc de Massif Central rams, the fecundity was $92 \%$, the fertility was $88 \%$ and the prolificacy was $104 \%$. Similar results we obtained in the control batch, that suggest the sustainability of crossing the Tsurcana Breed with Blanc du Massif Central rams to improve the weight of Tsurcana lambs.

The fertility rate of the Tsurcana ewes studied can be considerate as a good result which allows further use of the protocol used to synchronize the ewes.

The results were similar between the two batches concerning the studied reproductive

Table 1. Fertility, fecundity, prolificacy and pregnancy diagnosis in the two batches

\begin{tabular}{|c|c|c|c|c|c|}
\hline & \multirow{2}{*}{ Total } & \multicolumn{2}{|c|}{ Ultrasound examination at 55 days } & \multicolumn{2}{|c|}{ Ultrasound examination at 130 days } \\
\hline & & 50 & $100 \%$ & 50 & $100 \%$ \\
\hline \multirow{2}{*}{ Batch I } & Pregnant & 48 & $96.00 \%$ & 44 & $88.00 \%$ \\
\hline & Non-pregnant & 2 & $4.00 \%$ & 6 & $12.00 \%$ \\
\hline \multirow{2}{*}{ Batch II } & Pregnant & 49 & $98.00 \%$ & 47 & $94.00 \%$ \\
\hline & Non-pregnant & 1 & $2.00 \%$ & 3 & $6.00 \%$ \\
\hline \multirow{2}{*}{$\begin{array}{c}\text { Lambed } \\
\text { Tsurcana ewes }\end{array}$} & Batch I & 44 & & & \\
\hline & Batch II & 47 & & & \\
\hline \multirow{3}{*}{ Lambs } & Batch I & 46 & & & \\
\hline & Batch II & 48 & & & \\
\hline & & Fecundiy & Fertility & Prolificacy & \\
\hline \multicolumn{2}{|c|}{ Batch I } & $92.00 \%$ & $88.00 \%$ & $104.00 \%$ & \\
\hline \multicolumn{2}{|c|}{ Batch II } & $96.00 \%$ & $94.00 \%$ & $102.00 \%$ & \\
\hline
\end{tabular}

Batch II = Tsurcana ewes+ Tsurcana rams 
parameters (Tsurcana rams x Tsurcana Ewes and Blanc du Massif Central rams and Tsurcana ewes).

Acknowledgements: This work has benefited from financial support through the PN-II-PTPCCA-2013-4-1239 project, No: 152/01.07.2014, "Obtaining the Romanian meat lamb - OVICARO".

\section{REFERENCES:}

1. Dărăban S (2006). Tehnologia creșterii ovinelor. Ed. Risoprint, Cluj-Napoca

2. FAO STATISTICAL YEARBOOK (2014) Europe and Central Asia Food and Agriculture, Food and Agriculture Organization of the United Nations Regional Office for Europe and Central Asia Budapest

3. Groza IŞ (2006). Ginecologie, andrologie şi obstetrică veterinară - Compendiu, Ed. Academiei Române, Bucureşti
4. Haresign W (1992). Manipulation of reproduction in sheep, J. Reprod. Fertil, Suppl 45: 127-139

5. Henderson DC and Robinson JJ (2000). The reproductive cycle and its manipulation, in: Martin WB, Aitken ID., 2000, Diseases of sheep 3rd ed. Oxford: Blackwell Scientific Publications

6. Noakes DE, Parkinson TJ, England GCW (2009). Veterinary reproduction and Obstetrics, Ninth Edition, Saunders Elsevier, 708-716.

7. Padeanu I (2011) - Biotehnici de reproducere la ovine. Editura Mirton, Timisoara

8. Ptaszynska $\mathrm{M},(2009)$, editor $10^{\text {th }}$ edition of Compendium of animal reproduction, Publisher Intervet International

9. Rosa HJD, Bryant MJ (2003). Seasonality of reproduction in sheep, Review Small Rum Res, 48: 155-171 